\title{
KINEZITERAPIJOS POVEIKIS SENJORŲ GRIUVIMŲ PREVENCIJAI
}

\author{
Gabrielė Kasperavičiūtė $\dot{\mathbf{1}}^{1}$ Inesa Rimdeikiené $\dot{\mathrm{e}}^{1,2}$ \\ Lietuvos sveikatos mokslu universitetas ${ }^{l}$ \\ Lietuvos sveikatos mokslu universiteto ligonine Kauno klinikos ${ }^{2}$
}

\section{SANTRAUKA}

Tyrimo pagrindimas. Griuvimai - dažna vyresniojo amžiaus žmonių problema. Tai antra pagal dažnumą mirštamumo priežastis pasaulyje. Dẻl lūžių griuvimo metu prastėja gyvenimo kokybè ir didèja baimè nukristi pakartotinai. Naujausi moksliniai tyrimai teigia, kad raumenų stiprinimo ir pusiausvyros lavinimo pratimai yra svarbūs griuvimų prevencijai. Vyresniojo amžiaus žmonių, atliekančių specialius pratimus, baimė sumažèja, jie labiau pasitiki savimi atlikdami kasdienes užduotis. Ankstesniuose tyrimuose griuvimo prevencijos programos buvo taikomos bent pusę metų, todèl šiuo tyrimu buvo siekiama išsiaiškinti, kokių rezultatų galima pasiekti mažinant griuvimo riziką, kai lavinama pusiausvyra ir eisena, taikoma Otago pratimų programa 3 mènesius.

Tikslas - ịvertinti pagyvenusių ir senyvo amžiaus žmonių griuvimų rizikos, pusiausvyros ir eisenos rodiklių kaitą taikant 3 mėnesių trukmès Otago pratimų programą.

Metodai. Buvo tirti 22 asmenys. Vieną grupę sudare 9 pagyvenę, kitą - 13 senyvo amžiaus asmenys. Pagyvenusiųjų grupejje - 3 moterys, 6 vyrai. Senyvo amžiaus grupeje -10 moterų, 3 vyrai. Atrankos kriterijai: tiriamieji 65-84 amžiaus, vaikštantys savarankiškai, protinès būklès testo ịvertinimas $\geq 20$ balų. Tiriamiesiems buvo taikyta 3 mėnesių trukmès Otago pratimų programa 3 kartus per savaitę. Prieš tyrimą ịvertinta protinès būklès, griuvimų rizikos ir pusiausvyros bei eisenos rodikliai. Po tyrimo vertinta griuvimo rizika ir pusiausvyra bei eisena.

Rezultatai. Griuvimų rizikos ir pusiausvyros rodikliai pagerèjo vidutiniškai nuo 19,18 $\pm 2,09$ iki 21,41 $\pm 1,43$ balo, eisenos įvertinimas vidutiniškai pagerèjo nuo 17,64 $\pm 3,53$ iki 14,18 $\pm 3,03 \mathrm{~s}$. Lyginant griuvimų riziką ir pusiausvyrą tarp amžiaus grupių, didesnis pokytis nustatytas pagyvenusių žmonių grupeje (nuo 19,33 $\pm 2,06$ iki 21,67 $\pm 1,22$ ). Eisenos ịvertinimas, lyginant rodiklius tarp amžiaus grupių, vidutiniškai geresnis pagyvenusiųjų - nuo 18,11 $\pm 3,44$ iki 14,56 \pm 3 .

Išvada. Po 3 mėnesių kineziterapijos pagyvenusių ir senyvo amžiaus žmonių grupėse griuvimų rizika statistiškai reikšmingai sumažèjo $(\mathrm{p}<0,05)$, eisenos rodikliai grupėse statistiškai reikšmingai pagerèjo $(\mathrm{p}<0,05)$. Lyginant rodiklius tarp grupių tiek prieš kineziterapiją, tiek ir po jos, statistiškai reikšmingo skirtumo nenustatyta $(\mathrm{p}>0,05)$.

Raktažodžiai: griuvimai, eisena, pagyvenę žmonès, senyvo amžiaus žmonès.

\section{IVADAS}

Pastaraisiais metais pastebimas spartus populiacijos senejimas visame pasaulyje. Ilgejjant gyvenimo trukmei, visoje Europoje asmenis nuo 65 metų Pasaulio sveikatos organizacija (PSO) rekomenduoja laikyti pagyvenusiais (World Health Organization, 2011). Kas ketvirtas Europos Sajungos valstybės gyventojas yra sulaukęs 60 metų, Lietuvoje - kas penktas. Atlikti skaičiavimai prognozuoja, kad $2030 \mathrm{~m}$. trečdali Lietuvos gyventojų sudarys pagyvenę asmenys, o sulaukusių 80 ir daugiau metų padidès 1,5 karto (Zumeras, 2013). PSO asmenis skirstyti pagal 
amžių rekomenduoja taip: 60-74 metų - pagyvenusieji, 75-90 metų - senyvo amžiaus.

Literatūroje išskiriami dviejų rūšiu griuvimo rizikos veiksniai: išoriniai ir vidiniai. Išoriniai (aplinkos) veiksniai - erdvé, aplinka, vaikščiojimas nelygiais paviršiais, netinkamas apšvietimas, įvairios kliūtys, avalynè, slydimas lauke ant apledèjusių paviršių bei namuose ant patiestų kilimų. Vidiniams veiksniams priskiriama moteriška lytis, galvos svaigimas, sinkopè, kojų silpnumas, išgąstis, ūminès ligos, tam tikrų vaistų vartojimas bei regos, klausos, eisenos, pusiausvyros sutrikimai (Gazibara et al., 2017). Pastebima, kad eisenos ir pusiausvyros sutrikimai būdingi esant šioms būsenoms: emociniams, psichikos, neurologiniams ir jutimų sutrikimams, sergant infekcinėmis, metabolinėmis, širdies ir kraujagyslių ligomis (Cifu et al., 2018). Suletejęęs vaikščiojimo greitis yra dažniausias su amžiumi susijęs pokytis. Iprastai, sulaukus 60 metų, vaikščiojimo greitis mažeja apie 1\% per metus. D. Soto-Quijango'as (Soto-Quijano, 2017) išskiria veiksnius, lemiančius eisenos lètėjimą: sumažėjęs žingsnio ilgis, padidèjęs žingsnio plotis, sumažèjęs dubens pasvyrimo kampas, sumažejusi šlaunies tiesimo amplitudè, pèdos plantarinė fleksija, kojų raumenų jèga, sutrikusi pusiausvyra.

Griuvimo prevencijos programos yra viena iš pagrindinių kineziterapijos priemonių siekiant išvengti pagyvenusių ir senyvo amžiaus žmonių griuvimo (Prata, Scheicher, 2015). Reguliariai atliekami pusiausvyros, kojų jègos, lankstumo ir vaikščiojimo pratimai lavina pusiausvyrą bei eiseną. Užduotys pateikiamos įvairiomis formomis, kurios padeda stiprinti pagyvenusių ir senyvo amžiaus žmonių organizmą. Viena iš tokių priemonių yra Otago pratimų programa. Šis metodas yra efektyvus vyresnių asmenų griuvimo rizikai mažinti. Ji ypač efektyvi 80 metų ar vyresniems asmenims ir yra laikoma saugia, efektyvia, praktiška ir ekonomiška griuvimų prevencijos priemone (Martins et al., 2018).

Otago pratimu programa buvo sukurta Naujojoje Zelandijoje ir išbandyta atsitiktinès atrankos tyrimų metu. Rodikliai parodè, kad ši griuvimų prevencijos programa yra efektyvi siekiant išvengti vyresnių nei 65 metų asmenų griuvimo. Irodyta, kad asmenims, turintiems aukštą rizikos lygi griūti, jị sumažina iki 35\%. Ypač didelis efektyvumas pastebètas asmenų grupëje nuo 80 metų, kurie per pastaruosius metus buvo griuvę ir dèl ịvairių rizikos veiksnių bei neveiklumo buvo nusilpusi jų raumenų jèga, sutrikusi pusiausvyra. Ši griuvimų prevencijos programa yra sudaryta dviejų lengviausiai veikiamų griuvimo rizikos veiksnių - jègos ir pusiausvyros pratimų - pagrindu (Patel, Pachpute, 2015).

Vyresniojo amžiaus asmenys, kurie yra kritę, turi didesnę baimę nukristi, ir tai lemia jų veiklos ir mobilumo apribojimus, silpsta jų raumenų jẻga. Vyresnių asmenų, atliekančių specialius pratimus, baimė sumažèja, jie labiau pasitiki savimi atlikdami kasdienes užduotis (Røyset et al., 2019). 
Tyrimo tikslas - ịvertinti pagyvenusių ir senyvo amžiaus žmonių griuvimų rizikos, pusiausvyros ir eisenos rodiklių kaitą taikant 3 mènesių trukmės Otago pratimų programą.

\section{METODAI}

Tiriamieji. Buvo tirti 22 asmenys. Vieną grupę sudarẻ 9 pagyvenę asmenys, kitą - 13 senyvo amžiaus. Pagyvenusių asmenų grupejje buvo 3 moterys ir 6 vyrai. Senyvo amžiaus grupejje - 10 moterų ir 3 vyrai. Abiejų grupių tiriamieji atitiko šiuos kriterijus:

- tiriamujų amžius nuo 65 iki 84 metų;

- galintys vaikščioti savarankiškai;

- protinès būklès testas (angl. Mini Mental State Examination - MMSE) $\geq 20$ balų.

\section{1 lentelè. Tiriamųjų charakteristika}

\begin{tabular}{|l|c|c|}
\hline \multirow{2}{*}{ Rodikliai } & \multicolumn{2}{|c|}{ Vidurkis \pm standartinis nuokrypis } \\
\hline Amžius (metai) & \multicolumn{2}{|c|}{$75,55 \pm 5,4$} \\
\cline { 2 - 3 } Pagyvenę & $70,22 \pm 3,2$ & Tarp amžiaus grupių \\
Senyvo amžiaus & $79,23 \pm 2,8$ & 0,05 \\
\cline { 2 - 2 } & \multicolumn{2}{|c|}{$168,8 \pm 5,1$} \\
\hline Ūgis $(\mathrm{cm})$ & \multicolumn{2}{|c|}{$78,7 \pm 10,7$} \\
\hline Svoris $(\mathrm{kg})$ & \multicolumn{2}{|c|}{$22,27 \pm 1,31$} \\
\hline Trumpas protinès būklès testas (balai) & \\
\hline
\end{tabular}

\section{Tyrimo metodai}

Trumpas protinès būklès testas. Šio tyrimo metu ịvertinamos kognityvinès funkcijos. Testas sudarytas iš 19 užduočių, kuriomis vertinama orientacija vietoje ir laike, trumpalaikė atmintis, gebėjimas įsiminti, dėmesys, nurodymų suvokimas, kalba, gebẻjimas vykdyti žodines, raštu pateikiamas užduotis ir jas kopijuoti. Už tiksliai atsakytą klausimą ir atliktą užduotį skiriamas 1 balas. Jei surenkama mažiau negu 20 balų - pažeistos pažintinès funkcijos ir didelè demencijos ar delyro rizika. Rodiklių reikšmės: 0-10 - sunkus, 11-19 - vidutinio sunkumo, 20-23 lengvas kognityvinis defektas, nuo 24 balų - kognityvinio sutrikimo nèra (Rubright et al., 2016).

Tinetti pusiausvyros ir eisenos testas. Šio testo tikslas įvertinti asmenu griuvimo riziką. Jis sudarytas iš 2 dalių: pusiausvyros ir eisenos vertinimo. Testo užduotys vertinamos: 0,1 ir 2 balais. 0 balų reiškia funkcijos sutrikimą, 2 balai - tinkamą funkcijos gebejjimą atlikti. Galutinis vertinimas susideda iš 3 komponentų: eisenos, pusiausvyros ir kombinuoto eisenos bei pusiausvyros vertinimų. Balų suma - nuo 0 iki 28 . Eisenos testo didžiausia suma -12 balų, pusiausvyros -16 . Jei tiriamasis 
surenka mažiau nei 19 balų, yra didelè rizika griūti, nuo 19 iki 23 - vidutinè, nuo 24 - maža (Wee et al., 2016).

„Stotis ir eiti“ testas. Tiriamasis, atlikdamas testą, sèdi ant kèdès. Ji pastatyta prie sienos, nuo priekinių kẻdès kojų nubrèžta 3 metrų linija. Tiriamasis sėdi ant kèdès atsirèmęs ị atlošą. Išgirdęs žodị „Pradedam“, turi atsistoti nuo kèdès, eiti 3 metrus tiesia linija savo ịprastu tempu, apsisukti neprarandant pusiausvyros, grįžti atgal prie kèdès tiesia linija ịprastu tempu, apsisukti ir atsisèsti ant kèdès. Vyresniojo amžiaus asmenims testo atlikimo norma $<12$ sekundžių (Avers, Brown, 2019).

Otago pratimu programa. Šią pratimų programą sukūrè A. Campbell'as ir M. Roberston'as Otago medicinos mokykloje. Ji igyvendinta visoje Naujojoje Zelandijoje bendradarbiaujant nelaimingų atsitikimų kompensavimo korporacijai. Otago pratimų programa labiausiai taikoma griuvimų prevencijai tarp vyresniojo ir senyvo amžiaus asmenų. Ji orientuota lavinti kojų jègą atliekant pusiausvyros ir vaikščiojimo pratimus - didinama čiurnos sąnario apkrova, pakartojimų skaičius. Lankstumo ir pasipriešinimo pratimai atliekami kartojant 5 kartus, pusiausvyros pratimų metu padètis išlaikoma 10 sekundžių (Campbell, Robertson, 2003). Taikyta intervencija - Otago pratimų programa. Užsièmimų trukmė - 3 mèn. (po $30 \mathrm{~min}$ ), dažnis $3 \mathrm{k} . / \mathrm{sav}$.

Siekiant nustatyti kineziterapijos poveiki, tiriamieji vertinti du kartus - tyrimo pradžioje (Trumpu protinès būklès, Tinetti pusiausvyros ir eisenos, „Stotis ir eiti“ testais) ir pabaigoje (Tinetti pusiausvyros ir eisenos, „Stotis ir eiti“ testais).

Statistinė duomenų analizė. Statistinè duomenų analizė atlikta taikant „SPSS Statistics 22 " programinę ịrangą. Duomenys pateikti kaip aritmetinis vidurkis \pm standartinis nuokrypis $(\mathrm{x} \pm \mathrm{sn})$. Dviems priklausomoms imtims palyginti taikytas Wilcoxon'o kriterijus. Dviems nepriklausomoms imtims Mnno'o-Whitney'aus kriterijus. Skirtumai, kai $\mathrm{p}<0,05$, laikyti statistiškai reikšmingais.

\section{TYRIMO REZULTATAI}

Tyrimo metu nustatyta, kad visų tirtų asmenų griuvimų rizikos, pusiausvyros ir eisenos rodikliai (2 lent.), reikšmingai pagerèjo $(\mathrm{p}<0,05)$. Prieš tyrimą visi tiriamieji atliko Tinetti pusiausvyros ir eisenos testą. Nustatyta, kad $45 \%$ tiriamųjų turi didelę riziką nukristi, vidutinę riziką $-55 \%$ tiriamujų. Po tyrimo vidutinè rizika nukristi nustatyta $90 \%$, maža rizika - 10\% tiriamujų. Prieš tyrimą $10 \%$ tiriamụjų eisenos užduotị atliko ilgiau nei per 12 sekundžių, 90\% tiriamųjų užduotị atliko tinkamai. Tyrimo pabaigoje $36 \%$ tiriamujų užduotị atliko tinkamai. 
2 lentelè. Griuvimų rizikos, pusiausvyros ir eisenos rodikliai prieš kineziterapiją ir po jos

\begin{tabular}{|l|c|c|}
\hline Duomenys & $\begin{array}{c}\text { Griuvimų rizika ir pusiausvyra } \\
\text { (balai } \pm \mathbf{s n} \text { ) }\end{array}$ & $\begin{array}{c}\text { Eisena } \\
\text { (s } \pm \text { sn) }\end{array}$ \\
\hline Prieš kineziterapiją & $19,18 \pm 2,09$ & $17,64 \pm 3,53$ \\
\hline Po kineziterapijos & $21,41 \pm 1,43$ & $14,18 \pm 3,03$ \\
\hline Pokytis & 2,23 & 3,46 \\
\hline $\begin{array}{l}\text { P reikšmè prieš } \\
\text { kineziterapiją ir po jos }\end{array}$ & $\mathrm{p}<0,05$ & $\mathrm{p}<0,05$ \\
\hline
\end{tabular}

Tyrimo metu nustatyta, kad pagyvenusių amžiaus žmonių griuvimo rizikos įvertinimas statistiškai reikšmingai pagerejjo $(\mathrm{p}<0,05)$. Senyvo amžiaus žmonių grupejje griuvimų rizika reikšmingai sumažèjo $(\mathrm{p}<0,05)$. Lyginant rodiklius tarp grupių prieš kineziterapiją, statistiškai reikšmingo skirtumo nenustatyta $(p>0,05)$. Lyginant rodiklius po kineziterapijos, tarp grupių reikšmingo skirtumo taip pat nenustatyta $(\mathrm{p}>0,05)$ ( 3 lent.). Tyrimo pradžioje $33 \%$ pagyvenusių tiriamujų turẻjo didelę riziką nukristi, vidutinę $-67 \%$. Senyvo amžiaus grupèje didelè rizika nukristi nustatyta $54 \%$ tiriamujų, vidutinè $-46 \%$. Tyrimo pabaigoje pagyvenusių tiriamujų grupejje vidutinè rizika nukristi nustatyta $89 \%$, maža - 11\%. Senyvo amžiaus tiriamujų grupèje vidutinè rizika nukristi nustatyta $92 \%$, maža - $8 \%$ tiriamųjų. Didesnis pokytis nustatytas pagyvenusių žmonių grupejje.

Tyrimo metu nustatyta, kad abiejų grupių eisenos ịvertinimas statistiškai reikšmingai pagerèjo: pagyvenusių žmonių $-p<0,05$, senyvo amžiaus $-p<0,05$. Lyginant rodiklius tarp grupių prieš kineziterapiją, reikšmingo skirtumo nenustatyta $(p>0,05)$. Reikšmingo skirtumo nenustatyta $(p>0,05)$, lyginant rodiklius ir po kineziterapijos (3 lent.). Tyrimo pradžioje pagyvenusių asmenų grupès tiriamieji eisenos užduotị atliko ilgiau nei per $12 \mathrm{~s}$. Senyvo amžiaus grupejje $7 \%$ tiriamųu užduotị atliko tinkamai. Tyrimo pabaigoje pagyvenusių žmonių grupejje 35\% tiriamujų užduotị atliko tinkamai, senyvo amžiaus žmonių grupejje - 36\% tiriamujų . Didesnis pokytis nustatytas pagyvenusių žmonių grupeje. 
3 lentelè. Griuvimo rizikos ir eisenos rodiklių kaita tarp amžiaus grupių

\begin{tabular}{|l|c|c|c|c|c|}
\hline \multirow{2}{*}{ Rodikliai } & \multicolumn{2}{|c|}{ Prieš kineziterapiją } & \multicolumn{2}{c|}{ Po kineziterapijos } & Po KN \\
\cline { 2 - 5 } & Pagyvenę & $\begin{array}{c}\text { Senyvo } \\
\text { amžiaus }\end{array}$ & Pagyvenę & $\begin{array}{c}\text { Senyvo } \\
\text { amžiaus }\end{array}$ & $\begin{array}{c}\text { tarp } \\
\text { grupių }\end{array}$ \\
\hline $\begin{array}{l}\text { Griuvimų rizika ir } \\
\text { pusiausvyra pagal } \\
\text { Tinetti testą } \\
\text { (balai } \pm \text { sn) }\end{array}$ & $19,33 \pm 2,06$ & $19,08 \pm 2,17$ & $21,67 \pm 1,22$ & $21,23 \pm 1,58$ & $\mathrm{p}>0,05$ \\
\hline $\begin{array}{l}\text { Eisena pagal } \\
\text { „Stotis ir eiti“ testą } \\
\text { (s } \pm \text { sn) }\end{array}$ & $18,11 \pm 3,44$ & $17,31 \pm 3,68$ & $14,56 \pm 3$ & $13,92 \pm 3,14$ & $\mathrm{p}>0,05$ \\
\hline
\end{tabular}

Pastaba. KN - kineziterapija.

\section{REZULTATU APTARIMAS}

Atlikto tyrimo tikslas - įvertinti pagyvenusių ir senyvo amžiaus asmenų griuvimų rizikos, pusiausvyros ir eisenos rodiklių kaitą taikant 3 mėnesių trukmės Otago pratimų programą. Gauti rodikliai parodé, kad taikant šią pratimų programą griuvimo rizika sumažèjo, pagerèjo pusiausvyra ir eisena.

Atliekant šį tyrimą griuvimo rizika ir pusiausvyra vertinta Tinetti testu. Nustatyta, kad tiriamiesiems baigus kineziterapijos programą rizika griūti sumažèjo, ir gautas testo ịvertinimas statistiškai reikšmingai skyrèsi $(p<0,005)$. P. Nancy'io ir bendraautoriu (Patel, Pachputel, 2015) tyrimo metu taikant Otago pratimų programą ir lyginant Tinetti testo rodiklius, rezultatai statistiškai reikšmingai pagerèjo $(\mathrm{p}<0,001)$.

Anot T. E. Shubert'o ir bendraautorių (Shubert et al., 2017), vyresniojo amžiaus asmenys 3 metrų atstumą turi nueiti per mažiau nei 12 sekundžių. Jei „Stotis ir eiti“ testo rodiklis yra didesnis nei 12 sekundžių, vadinasi, rizika nukristi yra didelè. Jeigu rodiklis yra didesnis nei $20 \mathrm{~s}$, asmuo geba eiti tik lètai. Šio tyrimo metu gauta vidutinè reikšmė po kineziterapijos buvo $14,16 \pm 3,03 \mathrm{~s}$. Tai rodo, kad programą taikant ilgiau nei 3 mẻnesius yra galimybé pasiekti tinkamą $12 \mathrm{~s}$ ribą, nes tyrimo pradžioje nustatyta vidutinè reikšmė buvo apie $18 \mathrm{~s}$.

J. Lee'as su bendraautoriu (Lee, Yoo, 2017) siekè išsiaiškinti Otago pratimų programos efektyvumą norint sumažinti moteru griuvimo riziką. Buvo tiriama 30 vyresniojo amžiaus moterų, kurių Trumpo protinės būklès testo rodikliai siekẻ 24 balus ar daugiau. Tyrimo metu sudarytos trys grupès: pirmai grupei taikyta Otago pratimų programa, antrai - jogos pratimai, trečia Otago programos pratimus turëjo 
atlikti savarankiškai namuose. Visose trijose grupèse pastebètas rodiklių gerejjimas. Pusiausvyros rodikliai tokie patys, kaip ir mūsų tyrimo, kurie rodo statistiškai reikšmingą pagerèjimą.

V. Benavet-Caballer'as ir kiti (Banevent-Caballer et al., 2016) siekè išsiaiškinti Otago pratimų programos poveikị vyresniojo amžiaus asmenų griuvimo rizikos mažinimui. Buvo tirti 55 asmenys nuo 65 metų, neturintys kognityvinių funkcijų sutrikimo. Tyrimas truko 4 mènesius. Kineziterapijos metu vyko grupiniai užsièmimai, pratimai rodomi dideliame ekrane. Ištyrimo metu vertinta eisena, pusiausvyra, kojų funkcija bei ištvermè. Atlikus galutinị ištyrimą, nustatytas tirtų rodiklių pagerejjimas. „Stotis ir eiti“ testo metu pastebėtas rodiklių pagerejjimas. Mūsų atlikto tyrimo rodikliai sutampa su šio tyrimo gautaisiais. Tiriamųų eisenos vertinimas po taikytos griuvimo prevencijos programos parodè, kad testo atlikimo laikas sutrumpejjo.

Tyrimo metu pastebejjome, kad žmonès, atlikdami stojimo nuo kėdès pratimą, pradžioje laikosi abiem rankomis. Vèliau pradeda laikytis tik viena ranka. Taip pat atlikdami ir kitus pratimus, tokius kaip pasistiebimais, ejimas tiesiai ir pan., žmonès pradžioje laikosi abiem rankomis ịsikibę ị atramą, vèliau pradeda tik viena ranka, o kai kurie tyrimo pabaigoje bandydavo atlikti pratimus ir nesilaikydami. Nors moterys rodè didesnį norą atlikti pratimus, vyrų gauti rodikliai buvo geresni ir pratimus atlikti jiems sekėsi geriau. Tarp pagyvenusių ir senyvo amžiaus asmenų ryškesnį susidomèjimą pastebejjome iš senyvo amžiaus asmenų.

Apibendrinant tyrimo rezultatus galima teigti, kad 3 mėnesių trukmès kineziterapijos progama, skirta griuvimų rizikai mažinti, teigiamai veikia pagyvenusių ir senyvo amžiaus asmenų griuvimo rizikos mažèjimą, pusiausvyros bei eisenos rodiklių gerejimą. Otago pratimų programa yra efektyvus metodas siekiant mažinti griuvimo riziką.

\section{IŠVADA}

Po 3 ménesių kineziterapijos pagyvenusių ir senyvo amžiaus asmenų grupių griuvimų rizika statistiškai reikšmingai sumažèjo $(\mathrm{p}<0,05)$, eisenos rodikliai statistiškai reikšmingai pagerejo $(\mathrm{p}<0,05)$. Lyginant rodiklius tarp grupių tiek prieš kineziterapiją, tiek ir po jos, statistiškai reikšmingo skirtumo nenustatyta $(\mathrm{p}>0,05)$.

\section{LITERATŪRA}

Avers, D., Brown, M. (2019). Daniels and Worthingham's muscle testing: Techniques of manual examination and performance testing. St. Louis: Elsevier. P. 351. 
Benavent-Caballer, V., Rosado-Calatayud, P., Segura-Ortí, E., Amer-Cuenca, J., Lisón, J. F. (2016). The effectiveness of a video-supported group-based Otago exercise programme on physical performance in community-dwelling older adults: A preliminary study. Physiotherapy, 102 (3), 280-286.

Campbell, A., Robertson, M. (2003). Otago Exercise Programme to Prevent Falls in Older Adults. New Zealand: University of Otago. P. 1-71.

Cifu, D. X., Lew, H. L., Oh-Park, M. (2018). Geriatric Rehabilitation. St. Louis Mo: Elsevier. P. 241-245.

Gazibara, T., Kurtagic, I., Kisic-Tepavcevic, D. et al. (2017). Falls, risk factors and fear of falling among persons older than 65 years of age. Psychogeriatrics: The Official Journal of the Japanese Psychogeriatric Society, 17 (4), 215

Lee, J., Yoo, H., Lee, B. (2017). Effects of augmented reality-based Otago exercise on balance, gait, and physical factors in elderly women to prevent falls: A randomized controlled trial. Journal of Physical Therapy Science, $29(9), 1586$.

Martins, A. C., Santos, C., Silva, C. et al. (2018). Does modified otago exercise program improves balance in older people? A systematic review. Preventive Medicine Reports, 11, 231-239.

Patel, N. N., Pachpute, S. (2015). The effects of otago exercise programme for fall prevention in elderly people. International Journal of Physiotherapy, 2 (4), 633-639.

Prata, M. G., Scheicher, M. E. (2015). Effects of strength and balance training on the mobility, fear of falling and grip strength of elderly female fallers. Journal of Bodywork \& Movement Therapies, 19 (4), 646-650.

Røyset, B., Talseth-Palmer, B., Lydersen, S., Farup, P. (2019). Effects of a fall prevention program in elderly: A pragmatic observational study in two orthopedic departments. Clinical Interventions in Aging, 14, 145-154.

Rubright, J. D., Nandakumar, R., Karlawish, J. (2016). Identifying an appropriate measurement modelling approach for the mini-mental state examination. Psychological Assessment, 28 (2), 125-133.

Shubert, T. E., Goto, L. S., Smith, M. L. et al. (2017). The otago exercise program: Innovative delivery models to maximize sustained outcomes for high risk, homebound older adults. Frontiers in Public Health, 5, 54.

Soto-Quijano, D. (2017). Promoting health and wellness in the geriatric patient. Physical Medicine \& Rehabilitation Clinics of North America, 28 (4), 16-20.

Wee, C. E., Ames, T. D., Le, K. M. et al. (2016). Fear of falling correlates with subtle neuromuscular balance and strength deficits of fragility fracture patients. Aging and Disease, 7 (5), 585.

World Health Organization. (2011). Global recommendations on physical activity for health. Prieiga internetu: http://www.who.int/dietphysicalactivity/factsheet_recommendations/en

Zumeras, R. (2013). Pagyvenusiu žmoniu fizinis aktyvumas ir sveikata. Vilnius: Sveikatos mokymo ir ligu prevencijos centras. P. 5.

\title{
THE EFFECT OF PHYSICAL THERAPY ON FALL PREVENTION IN ELDERLY POPULATION
}

\author{
Gabrielè Kasperavičiūtė $\dot{1}^{1}$ Inesa Rimdeikiené $\dot{e}^{1,2}$ \\ Lithuanian University of Health Sciences ${ }^{l}$ \\ The Hospital of Lithuanian University of Health Sciences ${ }^{2}$
}

\section{ABSTRACT}

Background. Falls is a common problem of older people. It is the second common cause of mortality in the world. Fractures that occur during fall can cause deterioration in quality of life and increase the fear of falling. The newest science research suggests that strengthening and balance exercises are important for the 
fall prevention in older people. The older individuals who perform special exercises show a decrease in the fear of falling and an increase in self-confidence in daily tasks. Research shows that exercise programme to prevent falls lasted for half a year to see the result. In this study the main aim was to find the effect of physical therapy using Otago exercise programme for three months and to examine the results of preventing risk of falls, balance training and gait.

Research aim was to evaluate the efficacy of the 3-month Otago exercise programme on the risk of fall, balance and gait in elderly and old people.

Methods. Twenty-two persons (nine elderly and 13 old people) participated in this study. Selection criteria were: $65-84$ years of age, walking independently, mini mental state examination $\geq 20$. Participants received Otago exercise programme for 3 months. Procedures were performed three times a week. Parameters of mental state, risk of falling, balance and gait were measured.

Results. Risk of falls and balance parameters increased statistically significantly from $19.18 \pm 2.09$ to $21.41 \pm 1.43$ points. Gait parameters produced an average increase from $17.64 \pm 3.53$ to $14.18 \pm 3.03 \mathrm{~s}$. When comparing between age groups, reducing risk of falls and balance was more effective on elderly people from $19.33 \pm 2.06$ to $21.67 \pm 1.22$ points. Comparing gait between age groups, the greater change was found in the elderly people's group $18.11 \pm 3.44$ to $14.56 \pm 3 \mathrm{~s}$.

Conclusion. After 3 months of physiotherapy in the elderly and old people groups, risk of falls decreased statistically significantly $(p<0.05)$, gait parameters in both groups increased statistically significantly $(\mathrm{p}<0.05)$. When comparing results before and after physiotherapy, there was no statistically difference between both groups $(\mathrm{p}>0.05)$.

Keywords: falls, gait, elderly people, old people.

Gautas 20191129

Priimtas 20191213 